\title{
Humanist and Materialist Perspectives on Communication: The Work of Álvaro Vieira Pinto
}

\author{
Rafael Grohmann \\ University of São Paulo/FIAM-FAAM, Laureate International Universities, Faculty of Social \\ Communication Cásper Líbero, São Paulo, Brazil, rafael-ng@uol.com.br
}

\begin{abstract}
The present paper recovers the notion of technology present in the works of the Brazilian philosopher Álvaro Vieira Pinto written during the 1970s. Pinto made humanist and materialist contributions to the study of communication(s). The paper connects the author's contributions to communication theory with different theoretical and epistemological approaches, discussing the Zeitgeist of things, the post-human and the immaterial. Vieira Pinto anticipated theoretical questions that are relevant in current debates in communication theory.
\end{abstract}

Keywords: communication; technology; communication theory; Brazil.

\section{Introduction}

The field of communication studies, as any other scientific or social field (Bourdieu 1983), is sees disputes and conflicts over theoretical hegemony. A central theoretical and epistemological question the field has to ask, is: What is communication after all?

The possible answers to the questions regarding what and how to conduct research include the definition of the objects and problems of research. That is to say, through such exercises, theoretical-conceptual and methodological approaches are outlined within the field. This "place of disputes" involves two dimensions, namely, the epistemological and the political one. On the one hand, the epistemological debate takes place in conferences, seminars, and scientific magazines. On the other hand, we have to keep in mind what Brazilian author Muniz Sodré (2012) states about the prestige of communication studies: The field's prestige does not come from the "objectivity" of the generated knowledge, but from the production of social, cultural, and political value.

Communication Studies is today considered a central realm for the mobilization of knowledge coming from different areas of scientific knowledge. It operates in times of the "financialization of communication" (Sodré 2014). That is to say, "there is broad consensus today around the fact that communication, in its practice, is the mobilizing ideology of a new kind of workforce, corresponding to the present stage of goods production under global command" (Sodré 2014, 85). Furthermore, it is essential that the researcher be conscientious of his/her role in society and the consequences of his/her actions and choices.

Considering this scenario, we intend to address the concept of communication by observing its human and the material aspects and the concept of technology present in the work of Álvaro Vieira Pinto (2005a; 2005b). This Brazilian philosopher wrote one of his most relevant books, O Conceito de Tecnologia (The Concept of Technology) in 1973. He died in 1987. Nevertheless, his theoretical contribution is essential to the ongoing debates in communication studies in times where a) technology is either understood techno-optimistically or technopessimistically without room for contradictions; b) communication has been approached only from the perspective of "things", the "post-human", and the "immaterial". That being said, we should be careful not to naturalize or fetishize these concepts (Gusmão 2012). 


\section{2. Álvaro Vieira Pinto's Concept of Technology}

During the 1950s and 1960s, Álvaro Vieira Pinto was a professor at the Higher Institute of Brazilian Studies (IESB) $)^{1}$, located in the city of Rio de Janeiro. His work opposed the ongoing "structuralist trend" of the time and the "São Paulo school of sociology", which gathered names as Florestan Fernandes, Sérgio Buarque de Holanda and Fernando Henrique Cardoso. This school gained influence in the Brazilian social sciences and did not recognize the IESB's theoretical relevance. According to Norma Cortês $(2003,26)$, there was a feeling of "despise and repulse regarding the intellectual legacy that their ideas could leave to following generations of thinkers". The oblivion of his work consisted in an "attitude that reinforcedly rejected his way of understanding and explaining Brazilian society" (Cortês 2003, 26).

Vieira Pinto (1960) understands that struggles should also take place in the field of culture. He sees culture as a form of human expression and also as ways of developing a critical consciousness. Such consciousness is the way people express themselves but it is also a project of transformation (Martini 2009). In that sense, Vieira Pinto foresees that Brazilian philosophy should be simultaneously an expression and a criticism of the national reality. According to Bento Prado Jr. $(1985,6)$, "at this point [...] there is the establishment of a essentially practical project: philosophy in Brazil should not be the mere reproduction of the European metaphysics. It should be converted into an autonomous way of understanding and conducting a nation's destiny". We note that those ideas imply a project that supports an autonomous nation. Prado Jr. (1985) argues that Hegel influenced Vieira Pinto's works.

From a theoretical point of view, besides Hegel, Vieira Pinto was influenced by Karl Marx's historical and dialectical materialism, and to some extent also by Heidegger and Sartre. He was also considered one of Paulo Freire's teachers. During the 1970s, he translated some of the works of György Lukács into Portuguese. Amongst his authored books are Consciência e Realidade Nacional (Awareness and National Reality) and $A$ Sociologia dos Países Subdesenvolvidos (The Sociology of Underdeveloped Countries), besides the two volumes of $O$ Conceito de Tecnologia (The Concept of Technology). This last work was written in 1973, but the manuscripts were only recovered and published after his death ${ }^{2}$ in 2005. This will be discussed later on in this article.

Álvaro Vieira Pinto was not a communication studies thinker stricto sensu, but a philosopher concerned with Brazil's autonomous development. His work helps us theorize communication today. One of the relevant aspects of his work is the opposition made to cybernetics, mathematics, and information theory. From Vieira Pinto's point of view, one should not simply import "foreign" concepts, but also apply them for understanding Brazilian reality. The key aspect is to understand technology from the standpoint of "Southern epistemologies" (Santos and Menezes 2010).

What Vieira Pinto causes us to reflect on is how to understand communication within the context of the Southern hemisphere, considering the social, cultural, political, and also communicational specificities. Such an approach prevents us from essentializing technologies and communication, taking into consideration the inequalities and differences of the many communicational and technological contexts (Canclini 2005; Morley 2015).

More than Heidegger, Marx is Vieira Pinto's (2005a) main influence in the book $O$ Conceito de Tecnologia (The Concept of Technology). He understands technique and technology within the framework of historical materialism, which presupposes a dialectic perspective. Technology is taken as an "epistemology of the technique". "Only historical and dialectical materialism enables the understanding of the human genesis for it explains the condition of social being" (Pinto 2005a, 189-90). Contradictions are inherent to historical movements: They are not emancipation only, nor domination only, nor the "thousand wonders", nor the "greatest nightmare in the universe". The point is that one should not celebrate or demonize technologies, but understand their contradictions and possibilities in real and material life. Based on that, Vieira Pinto's starting point is to understand technology considering the social subject and human labour.

\footnotetext{
${ }^{1}$ Instituto Superior de Estudos Brasileiros (ISEB).

${ }^{2} \mathrm{He}$ was born in 1909 and died in 1987.
} 
Marx stated in the Grundrisse (2011) that the capital production process is also a technological process, related to what he understands as "machinery". However, neither the machine nor nature is the protagonist of the process. Rather human labour is the production process's subject:

nature builds no machines, no locomotives, railways, electric telegraphs, self-acting mules etc. These are products of human industry; natural material transformed into organs of the human will over nature, or of human participation in nature. They are organs of the human brain, created by the human hand; the power of knowledge, objectified. [...] To what degree the powers of social production have been produced, not only in the form of knowledge, but also as immediate organs of social practice, of the real life process (Marx 1973, 638).

Technology is part of social praxis and not an idealization or a must-be. Vieira Pinto (2005a) writes that "all possibility of technological development is connected to the development process of the productive forces of society" (Pinto 2005a, 49). According to Vieira Pinto, the study of technologies must take into consideration the constitutive authenticity of the human being. The human being is humanized trough his/her capabilities of communication and work (Figaro 2014b). Communication and technologies are indissolubly connected to the productive processes as categories that ground the social. Vieira Pinto (2005a) argues that work reveals society in all its different aspects. Technologies are invented to meet the human needs and to relieve humans from toil. "Humans create nothing, invent nothing nor produce anything outside the expression of their needs, having to face contradictions within reality" (Pinto 2005a, 49).

Humans are the only animals able to be productive and also produce themselves. For Vieira Pinto (2005a), humans are a "technical animal": "technique is present, by definition, in every human act" (Pinto 2005a, 62). Nevertheless, technique is subordinated to humanity, because history is not a product of technique. Technique is not the engine of the historical process.

With that being said, the author opposes the "substantialization of technique", which essentializes and overshadows the role of humans in their own production, "as if machines were data without a culture, with no origins nor social character, but appearing spontaneously and working by themselves" (Pinto 2005a, 180). It is clear that Vieira Pinto (2005a) argues for a more humanist notion of technique in opposition to the naturalistic concept of the machine. Machines don't ever disconnect from humans. For example, "the socalled 'electronic brains' are just electronic. The brain is in another place, in the heads of the inventors and constructors" (Pinto 2005a, 93).

Technologies are a product of human culture as algorithms are the result of human labour accumulated over time. There would not be iPhones and Google Glasses if it were not for the historical and technological development of society. Techniques do not stand still. They move forward because of culture and labour. To forget history means to produce theories that reflect the hegemonic foundations of society. An example of such reified theories is mediatization theory (Ampuja 2015).

Vieira Pinto (2005a) rejects speaking of a "technological era" or a "technological explosion" because humans have always produced new techniques and technologies. Likewise, he criticizes the concept of "consumer society", since, for him, all societies are favourable to consumption, including pre-historic communities. So, rejecting expressions such as "technological explosion", Vieira Pinto already criticized in 1973 what is considered to constitute "new" societal developments in 2016. For Vieira Pinto, such expressions are an ideology that mobilizes knowledge in order to reinforce power structures of power.

Vieira Pinto criticizes not only the concept of technology, but also the one of communication. He offers a starting point for a "theory of communication": Human communication in general "has nothing to do with the sensationalism of the current 'informatic' discoveries. Without taking into consideration this initial concept, we will hardly be able to clarify the problems of the theory of communication" (Pinto 2005b, 479). 
Communication can be defined then as a relationship derived from human activity. Álvaro Vieira Pinto's definition of communication is similar to that of Marx and Engels (2007) in The German Ideology.

"Things" (like the automatons) do not communicate because they do not have an existence nor do they perform social interaction and, therefore, they do not work. In the second volume of his book, Vieira Pinto mostly criticizes Marshall McLuhan (1969) and the mathematical theory of information. He says that both lack a non-idealistic dialectic perspective. According to Vieira Pinto, "human existentiality, in its distinctive trace, cannot be apprehended in communication, which is exactly what characterizes us and set us apart from the 'animal kingdom'” (Pinto 2005b, 478).

Álvaro Vieira Pinto's definition (2005b) of communication is very different from the one by Weaver (1978). It is closer to Raymond Williams's $(1977,2005)$ cultural materialism that sees communication as a means of production and as part of the concrete and practical material life of individuals (see Fuchs 2015, chapters 2+3). Álvaro Vieira Pinto is not interested in establishing a theoretical model of communication, as Stuart Hall (2003) is. He instead is interested in philosophically debating communication

Álvaro Vieira Pinto (2005a, 2005b) argues that humans have always had the means necessary for communicating with each other. To consider the human in its integrity as the centre of a theory of communication means to set a distance to linear and deterministic concepts of communication. Vieira Pinto (2005a) puts humans before technologies, not only as "senders" or "receivers", but as "social subjects". "The unity between form and content in technology expresses the dialectic character of the process by which humans act at the same time as authors and receivers of the produced cultural and economic assets" (Pinto 2005a, 283). Humans produce and are produced in the interrelationship between themselves and technologies while acting and receiving.

Álvaro Vieira Pinto $(2005 a, 2005 b)$ suggests that communication and technology are understood in a dialectic way. Human subjects are not an indistinct crowd. They are active in the process of building the world. The perspective Pinto adopts on the social subject is close to that found in Raymond Williams' (1960) works:

I do not think of my relatives, friends, neighbours, colleagues, acquaintances, as masses; we none of us can or do. The masses are always the others, whom we don't know, and can't know. Yet now, in our kind of society, we see these others regularly, in their myriad variations; stand, physically, beside them. They are here, and we are here with them. And that we are with them is of course the whole point. To other people, we also are masses. Masses are other people. There are in fact no masses; there are only ways of seeing people as masses (Williams 1960, 318-319).

Communication should then be understood within the reality of humans and their material practices. It would be "easy to convince social rulers that the management of informational means constitutes the most powerful tool to incite human beings to follow the paths [...] that the dominant sector is willing to impose to the larger part of human kind" (Pinto 2005b, 488).

In sum, we are able to understand technologies in relation to the communicational processes and their circulation. Technological conditions of production and consumption are materialized in messages, in social subjects and in devices. One should avoid t dividing the subject into small boxes in a reductionist manner. In that sense, Scolari (2009) criticises digital Taylorism's concept of the "user", in which subjects are reduced to their "usages" and "clicks".

Technologies respond to the needs of human beings. They therefore work as "mediation" between the human being and nature. Technique may generate transformations, which modify the production process. But, technique cannot be its own agent because it derives from human knowledge and "belongs to the real subject, the humans, meaning, in social terms, the working masses" (Pinto 2005a, 174). In that sense, a real change would only happen following the transformation of the societal conditions, the conditions made by and shaping the working class. Álvaro Vieira Pinto's message is that technology alone does not 
change anything. Therefore, the author rejects the assumption that machines rule humanity and also the belief that it can save ${ }^{3}$ humans.

The hope of getting "salvation" from the very machines is introjected in the worker, while his/her attention deviates from the fundamental things that he/she should have been claiming and making his/her complaint about (Pinto 2005a, 168).

That being said, Vieira Pinto argues for a concept of communication and technology that focuses on social change. Technologies are produced and consumed in unequal wayswhich is not a synonym for "different" ways (Canclini 2005) - by the different social classes. We must look at communication and technologies from the perspective of the labour theory of value (Marx 1980) and we should question the exploitation of the working class with regard to technologies because "the relationships of class exploitation are determined by the way the surplus labour is extracted from immediate producers" (Saad-Filho, 2011, 64). For whom are technologies useful? How is its value produced? What exactly are the working conditions of those who produce these technologies?

Therefore, social classes have not disappeared within the emergence of the Internet and other contemporary communications (Murdock 2009). They are simply going through a metamorphosis, since technologies do not evolve apart from societies. As Vieira Pinto says (2005a, 87-88),

the powerful classes have always had servomechanisms at their disposal, whether they were the pharaohs' or satraps' slaves, the feudal barons' horses, or the mechanical mills, now perfected with electronic and autonomous character [...]. Much of what has been said by the new science of cybernetics has, in fact, always existed under other names, but with the same essential role regarding humans.

In sum, Álvaro Vieira Pinto wants us to reflect on communication and technology: a) in a dialectic way, considering the material conditions of life and understanding communication and technology as a product of human work/labour. His perspective clashes with an idealistic view of communication that regards "materiality" only as a synonym for media devices, Vieira Pinto b) considers class struggles and inequalities, taking into account the production of surplus value and exploitation. He c) analyzes the possibilities of social transformation according to different historic realities with the purpose of emancipating the working class.

To analyze the technological reality of the global South is not the same as to theorize it from the perspective of Europe. Global geography matters in communication studies (Morley 2015). Latin America produces theoretical knowledge on communication that often has distinct perspectives. In that sense, Álvaro Vieira Pinto's contribution to communication studies should be analyzed as aiming at the future and not as a relic from the past. How can we place his work amongst others and combine it with different theoretical frameworks that currently try to define communication?

\section{Theoretical Implications for Communication Studies: Convergences and Di- vergences}

To place, in Bourdieu's terms (1983), an author within a scientific field means to understand not only his/her theoretical position, but also the possible theoretical dialogues s/he establishes with others. Such dialogues allows us to reflect on convergences and divergences. We can picture imaginary dialogues trying to understand the theoretical implications for contemporary communication studies and to develop the roots of a scientific road map.

It is an important epistemological task to ask how a theory conceives of human subjects. Vieira Pinto (2005a, 2005b) asks this question from the perspective of Marxism. He is, like Lukács, interested in an ontology of social being (see Fuchs 2016 [chapter 2] for a discus-

\footnotetext{
${ }^{3}$ These verbs-"dominate" and "save"-are full of theoretical, religious and political meanings.
} 
sion of the relevance of Lukàcs' Ontology of Social Being for communication theory). His approach is not based on the liberal concept of the individual, but on the human being that is at the same time individual and social. According to Lukács ${ }^{4}(1980,67)$, "the development of a mode of being consists in the gradual-contradictory and uneven-acquisition of predominance by its own specific categories". This formulation is equivalent to saying humans as "the producers of their conceptions, ideas [...] [are] conditioned by a definite development of their productive forces and of the intercourse corresponding to these, up to its furthest forms" (Marx and Engels 1939, 13).

The understanding of reality starts with active, real subjects in concrete and practical life. According to Marx and Engels $(1969,13)$, "All social life is essentially practical. All mysteries which lead theory to mysticism find their rational solution in human practice and in the comprehension of this practice". Praxis has both an objective and a subjective dimension. The primary aspect of the notion of the social being is the dimension of relationships. The relationships and the connections between "subject/being" and "object/world" are key for comprehending reality and its contradictions, creation and alienation. Social praxis is what, according to Figaro $(2014 a, 4)$, "makes the subject a being of communication. This is a process that feeds itself, a dynamics explained trough the human ontogenesis and phylogenesis".

Therefore, a Marxist theory of communication must consider communication as a material practice. It asks "how labor and language are mutually constituted, and how communication and information are dialectical instances of the same social activity, the social construction of meaning" (Mosco 2009, 44). Álvaro Vieira Pinto's notion of technology is based on this epistemological background.

Communication theory asks questions about "what is specifically communicational?" (Signates 2013). Communication studies has its own perspectives, approaches, models, theories, and points of view that are always articulated with positions from other fields. According to Baccega $(1998,103)$, re-significations "result, obviously, in new epistemological positions".

One of the recurring criticisms of communication studies is that some authors or works take a "sociological approach", understood in a pejorative sense. Such criticism could be directed to Álvaro Vieira Pinto (2005a 2005b), too. But how can we properly understand interactions and communication relationships without taking into consideration the society we live in? As Wolton argues $(2003,16)$, "there is no communication theory without an implicit or explicit theory of society". Notions of power and society are involved even when they are not explicitly theorized. After all, science is produced from a determined place, point of view and temporality. Lukács $(1980,14)$ states that, "science grows out of life, and in life itself, whether we realize this or not, we have spontaneously to behave ontologically". Vieira Pinto's contributions to communication studies understand communication in the context of human subjects' concrete and material reality. That being said, from which perspectives does the author diverge from?

First, as we have already noted, he diverges from cybernetics, a field created during the second half of 1940's by Norbert Wiener (1940). Vieira Pinto $(2015 \mathrm{~b}, 16)$ understands that "cybernetics as a whole is a complete cybernetic machine available to mankind" and it counts as a great feedback as living beings are known exactly for their retroaction circuit. According to the Brazilian author, cybernetics is the expression and result of class society:

All the concepts, methods and machinery that compound cybernetics and that it manipulates have that base explicitly or implicitly. They result from the existence of mankind and from the effects of the divided society structure it belongs to. They reflect the needs of human existence (Pinto 2005b, 31).

So the notion of social subject to cybernetics is completely different from that of Marxism. To Vieira Pinto $(2015 b, 19)$,

\footnotetext{
${ }^{4}$ Álvaro Vieira Pinto (2005a; 2005b) does not quote Lukács in O Conceito de Tecnologia (The Concept of Technology). So we are presenting here possible relationships based on similar notions on the social subject.
} 
The relationship between mankind and cybernetic machines will be satisfactorily resolved if we recur to a dialectic logic. Dialectic thinking is known for considering the object or theme of study in the perspective of historical development. It understands the object for its genesis, for the connection established within nature and for the qualities observed about them.

Information theory's mathematics (Weaver 1978) in comparision to dialectical philosophy understands communication as the sole transmission of information. It uses terms such as "message", "channel", or "signal" for analysing transmission. In the perspective of Vieira Pinto cybernetics is based on the naive belief that information is the engine of history and social relations.

Marshall McLuhan (1969)'s theory focuses on the medium. It is a medium theory that sees the "means" as the central dimension of communication and thus reduces communication matter to technology and media devices. The means of communication then "become the content of the ones which appear later and [...] they define the way the world is" (Rüdiger $2011 b, 131)$. A deterministic and non-dialectical approach to reality is assumed in favour of a materiality different from the one claimed by Vieira Pinto (2005a, 2005b). For McLuhan, not the materiality/concreteness of social life matters, but the media devices' materiality (Kherckhove 2006).

McLuhan's perspective misses the human being as the core of its theoretical concepts. Vieira Pinto (2005a) criticizes in this context the notion of the "electronic brain". Comparable concepts can today be found in theories of post-humanism (see Hayles 1999, Santaella 2007). Vieira Pinto's (2005a, 2005b) concept of communication is by definition opposed to post-humanism. It understands that the humans can't fuse with something machinic because technology is planned by the human being. If we follow the Brazilian philosopher's thought, then post-humanists have to some extent a linear concept of history and tend to construct celebratory, uncritical theories of technologies. They forget that humans produce technologies. Scientific knowledge based on biology, engineering and information systems is developed by human labour and not by cyborgs. Besides that, the fact they focus on the posthuman veils that such "distributed intelligence" stands in the context of capitalism and its production of surplus-value. Rüdiger $(2011 a, 214)$ argues in this context that "we are in the middle of a post-humanist situation, whose power and interest come from the fact of being partially inserted in the business and technological gears that structure our civilization" (Rüdiger 2011a, 214).

Therefore, based on Vieira Pinto (2008), we can say that praising technique and the technocrats that control it lets us forget how political interests shape the same technique. Devices are not mere techniques. They are shaped by power relationships. Media-centric, cybernetic and post-humanist theories are a manifestation of the dominant mode of production or what McGuigan (2009) terms "cool capitalism" (McGuigan 2009). According to Muniz Sodré (2002, 22), techno-deterministic ideologies hide media devices' social dimension behind technology. Sodré (2002) agrees with Vieira Pinto (2005a, 2005b) that in contemporary society communication cannot be understood apart from the capitalist mode of production. The Finnish scholar Marko Ampuja (2015) argues in this context that authors such as Manuel Castells fetishise the "digital sublime". He says that "emancipation does not depend on the transformation of the technological structures, but more exactly on the transformation of the political systems and structures of private power in which those are incorporated" (Ampuja 2015, 66). Ampuja advances the view that an analysis focused only on the technical devices "should be treated with suspicion" (Ampuja 2015, 66).

According to Álvaro Vieira Pinto (2005b), information is far from being the engine of history. It is otherwise moved by history:

It [Information] is represented by the only existing historical factor, mankind, who invented it and operates it. Information clearly cannot be the engine of history, even in the misunderstood conception of its autonomy as some in cybernetics want it. But it could be seen as the "engine of history" if we understand it in a dialectic way and carrying the signs of mankind's interference in the transformation of reality. That task can either be 
advanced by direct social action or indirectly with the development of physical instruments. [...] [Such a concept is] only [...] another way of saying that human beings are the true authors of their own history. However, when we refer to the social action of humans mediated through instrumental gadgets, we are in fact drawing the picture of social contradictions present in historical structures separated in classes (Pinto 2005b, 296-297).

Besides the approaches already discussed here, the concept of communication as proposed by Álvaro Vieira Pinto (2005a; 2005b) is also quite different from two contemporary approaches popular in communication studies: The fist is Bruno Latour's $(2009,2012)$ Actor Network Theory (ANT). The second is Italian Autonomist Marxism, as represented by the works of Michael Hardt and Antonio Negri (2005), who have worked on the notion of "immaterial" labout ${ }^{5}$.

ANT is widely spread in Brazil today ${ }^{6}$. Latour $(2009,2012)$ conceives the social by including associations and technologies in the notion of actants. His argument is more refined with regard to the post-human, as does not assume that machines can replace humans.

How could the anthropos be threatened by machines? It has made them, it has put itself into them, it has divided up its own members among their members, it has built its own body with them. How could it be threatened by objects? They have all been quasisubjects circulating within the collective they traced. It is made of them as much as they are made of it. It has defined itself by multiplying things (Latour 1993, 137-138).

Humans are not "threatened" by machines. But for Latour society and the social do not exist and they "have to be retraced by subtle changes in connecting non-social resources" (Latour $2005,36)$. Latour argues that the human sciences have kept the "human being" as the centre of attention for too long and they did not take into consideration "hybrids" and the fact that human beings are also "made of objects".

Latour's ANTs has in Brazil mainly been introduced by the work of André Lemos ${ }^{7}$ (2013), such as his book A Comunicação das Coisas (The Communication of Things). To him, "human beings communicate. As things do too. We communicate with things and they make us do things, regardless if we want it or not" (Lemos 2013, 19). It should be stressed that for Lemos (2013), as for Latour (2012), there is not a total depreciation of the human being. Lemos for example argues that "the mediation with non human beings is a determining part of the human being" $(2013,21)$. However, both authors see "subjects" and "objects" as having equal importance and see them as hybrids, with things being able to communicate. Thus, communication is in ANT part of the devices' materiality (Lemos 2013, 22) and not of social life's materiality of social life, as in the work of Vieira Pinto (2005a, 2005b). It is this attempt of equalising the human and technology that separates actor-network theory from Vieira Pinto's work. Vieira Pinto does not understand "subjects" and "objects" as "hybrids". For him, relationships have the priority. He stresses the central role of the "social subject" the Marxist ontology of the social being.

Vieira Pinto (2005a) diverges from ANT because he sees the social being as "the master of the situation". Things can do "things", but they do not interact, communicate, or perform work. Human beings produce gadgets. Making this argument does not disregard the fact that technological devices are part of human everyday life. They are also part of social praxis, but

\footnotetext{
${ }^{5}$ Other relevant approaches are in this context the theory of the "humanist liberal techno-utopia" (Rüdiger, 2011a), Pierre Lévy's (1999, 2014) concepts of "collective intelligence" and the "semantic sphere".

${ }^{6}$ That fact can be verified on Brazilian conferences and scientific journals. According to Segata (2014), the Brazilian Cyberculture Association "has organized more than 7 national symposiums. Bruno Latour and his actornetwork theory are present in at least half of the debates" (Segata 2014, 84). Massimo di Felice is another renowned Brazilian author, who makes use of actor-network theory (e.g. di Felice 2013).

${ }^{7}$ André Lemos is one of Bruno Latour's followers in Brazil. Latour is the main reference in his book $A$ Comunicação das Coisas (The Communication of things). According to Lemos $(2013,23)$, "the existence of a theory that faces mediators without giving too many privileges to classic social actors (the subjects) can be very stimulating to the field of communication and studies of cyberculture in Brazil".
} 
it is not simply possible to use the ontology of social being as a digital ontology or an ontology of the digital objects.

Another approach relevant in the human sciences that has found some level of resonance in communication studies is the one by Hardt and Negri (2005). Their approach includes reflections on the "immaterial". Negri is a representative of Autonomist Marxism. Also Spinoza has influenced $\mathrm{him}^{9}$, for example in respect to the concepts of desire and potentia. They oppose immaterial labour to industrial labour. For Hardt and Negri (2005), immaterial labour produces cooperation, communication and social relationships: "Producing communication, affective relationships, and knowledge, in contrast to cars and typewriters, can directly expand the realm of what we share in common" (Hardt and Negri 2004, 104). Immaterial workers would be more "autonomous" and would not so much depend on employers. A new kind of capitalism that is based on the immateriality of products, the workforce and communication itself, would have emerged. However, all work and communication have material aspects, as Vieira Pinto (2005a, 2005b) argues. Despite not referencing Vieira Pinto, Marcos Dantas (2012, 17-18) takes a similar approach:

\begin{abstract}
Information work is material because it involves transformations in the human body and its mind through suitable prostheses (tools and technologies), materials carrying signs that contain value for the sign they carry. Immaterial work only exists if we are talking about the one done by God in the act of creation (Dantas 2012, 17-18).
\end{abstract}

One of Hardt and Negri's mistakes (2005) is to disregard human labour when dealing with technologies. They also detach the question of so-called immaterial labour from the labour theory of value. The production of surplus-value undergoes a metamorphosis in capitalism, but that process is not hidden: There is a reorganization of the logic of capital valorization and of the working class's subordination. "Even if we consider information as the by-product of so-called immaterial labour, it is still created by exploited and unpaid labour-time" (Amorim 2009, 139). Žižek (2012) also criticizes the authors of Empire and Commonwealth for being influenced by the ideologists of the 'post-modern' capitalism and by what Vieira Pinto (2005a) understands as ideologists of the "technological explosion". According to Žižek $(2012,19)$, the paradox is that Negri celebrates the information revolution as a new potential for overcoming capitalism, whereas the ideologists of the information revolution celebrate informational capitalism.

McLuhan's theory, ANT, posthumanism, cybernetics, and Autonomist Marxism diverge from Álvaro Vieira Pinto's theoretical position. These approaches have all influenced communication studies. It is important to emphasize that this paper does not have the intention to delegitimize the existence of these theories within communication studies. A diversity of theories strengthens the field. However, certain theoretical hegemonies explain why Vieira Pinto and Marxist thought in general have for a long time been "forgotten" as important approaches for theorising communication. We need to think beyond the academic Zeitgeist and ponder if what some see as "yesterday"'s authors are in fact not today's authors. The point is to advance communication theories that do not reify, but criticise cool capitalism (McGuigan 2009).

\title{
4. Pinto's Relationship to Current Debates in Communication Theory
}

There are authors whose works are connected to Álvaro Vieira Pinto's concepts and ideas as they see technologies and communication from the perspective of human work, concrete and material reality, social classes, and the labour theory of value. In that sense, his work shows the importance of communication and technology in the work environment and in productive processes considering that communication is also a mean of production, as Raymond Williams $(1977,2005)$ used to stress.

\footnotetext{
${ }^{8}$ Topic also dear to authors like André Gorz and Mauricio Lazzarato.

${ }^{9}$ The Dutch author also influenced a number of philosophers, including the French Gilles Deleuze.
} 
Communication and its material means are intrinsic to all distinctively human forms of labour and social organization, thus constituting indispensable both of the productive forces and of the social relations of production. [...] Means of communication, both produced and as means of production, are directly subject to historical development (Williams 2005, 50).

Being part of human activities, communication and work are present in the concrete daily lives of the social subjects. "Thinking and communicating for Marx are processes of production embedded into humans' everyday life and work. Human beings produce their own capacities and realities of thinking and communication in labour and in social relations" (Fuchs 2015,13 ). In that sense, there is no work without communication. Communication that is related to the production process is developed in connection with the human subject's productive activities. Communication is therefore an important force in class struggles.

In society's contemporary situation, we find a lot inhumanity and disaffection for the working class. The fetish of capitalism also circulates in speech, for example when we hear people saying that "Facebook enhances sociality and is not a form of exploitation", "when you work on something you love, it is not labour", or "labour is cool". In labour, we can see the blurring of the boundaries between "labour time" and "free time", between labour and leisure. A typical example is the labour of freelance journalists (Grohmann 2012). Küklich (2005) uses the expression playbour (play + labour) to characterize such processes. He shows how meaning circulates in the work environment as in a "game". As a result, poor working conditions are legitimatized in the name of being just a "game". However, the playbour dynamic is not present in all sectors of the working class.

We can identify then a positively valued grammar that Mészáros (2008) terms "semantic convergence". Creativity, innovation and entrepreneurship are part of that grammar and they help to legitimate and justify the accumulation of (Ross 2009, McGuigan 2009 ${ }^{10}$, Illouz 2011, Huws 2014, Ampuja 2016). Ampuja $(2016,30)$ argues in this context:

Since social power in capitalism is based on inequalities between classes, innovation, too, is tied to these inequalities. Decision-making power over what kind of technological innovations will be produced are very unevenly distributed, as are the social consequences of their production, such as in the case of how high-risk financial innovations contributed to the global economic crisis that has caused massive social polarizations and instability.

Vieira Pinto (2005a, 2005b) analysed communication in relation to the material practices of human beings, which includes the dimension of work. The materiality of information and communication also matters in the context of digital media (Huws 1999, Huws 2014, Fuchs 2014a, Fuchs 2014b). Huws states that "it is not necessary to develop a new economics of weightlessness. On the contrary, we must reinsert human beings, in all their rounded, messy, vulnerable materiality-and the complexity of their antagonistic social relations-at the very centre of our analysis" (Huws 1999, 52).

The production of goods related to digital media and technologies go beyond the dimension of the idealized and superficial coolness of Silicon Valley ${ }^{11}$. They involve work conditions similar to slavery, for example, in the mineral extraction needed for computers and in the poor working conditions that Chinese workers face in the assemblage of laptops and cell phones at Foxconn. Fuchs $(2015,208)$ argues in this context:

The working lives of Muhanga, Lu, Bopha, Mohan, Bob, and Ann seem completely different. Muhanga extracts minerals from nature. Lu and Bopha are industrial workers. Mohan, Bob and Ann are information workers creating either software or designs. They work under different conditions, such as slavery, wage labour, or freelancing. Yet they

\footnotetext{
${ }^{10}$ The author would name that "surplus love".

${ }^{11}$ Casaqui and Riegel $(2009,163)$ argue that "the work environment is often associated in the Google scenario with creativity, easygoingness, modernity, and young life. It now becomes the show that sublimates the competitive character and other negative connotations related to that area of human activity".
} 
have in common that their labour is in different ways related to the production and use of digital technologies and that ICT companies profit from it.

Digital media studies cannot be understood independent from the rest of the capitalist model of production. It entails aspects such as mining, hardware assemblage, engineering, software development, chemistry work, design, journalism, marketing, call centre labour, or audience labour.

The growing visibility of apparently dematerialized labour, dependent on information and communications Technologies, has sometimes served to obscure the reality that this "virtual" activity is dependent on a highly material basis of physical infrastructure and manufactured commodities, most of which are produced out of the sight of observers in developed economies, in the mines of Africa and Latin America, the sweatshops of China, and other places in the developing world (Huws 2014, 157).

Digital technology cannot exist without digital labour. Huws (2014) points out that a significant part of the world's workforce is involved in these types of jobs. That is why it is important to understand their role in global capitalism, the composition of the workforce, and the class relationships it relates to. The global workforce is delocalized and diversified but it is nonetheless a class that has to work for earning a living (Antunes 2001). Ampuja (2016, $31)$ argues in this context:

These structural-material dimensions are not disconnected from cultural-ideological ones. This includes the promotion of entrepreneurs as current popular idols in the media (in many reality TV shows, for example) as well as the commodity fetishism attached to new ICT products as paradigmatic symbols of "cool capitalism".

Labour, class and exploitation still exist in digital capitalism. So we believe that Alvaro Vieira Pinto's ideas can be connected to recent developments in critical communication studies. An important first step is to generate visibility for this author, who has been forgotten in his own country.

Some questions can be raised in respect to Viera Pinto's work: How can countries in the "South", as those from Latin America and Africa, resist the "North"'s hegemony in communications and communication studies? How can we create our own communicational alternatives without importing or imitating others? How do inequality and class struggle manifest in the realm of communication and communicative labour in the "South" and in the globalizing and globalized world (Ampuja 2013). It is necessary to analyse technology and communication in the context of labour, social class and value. This approach involves analysing human subjects' concrete and material life. Class struggle takes place in the social fields of communication and labour. Álvaro Viera Pinto's works remind us of the importance of taking a critical approach in the study of communication and that thinkers from the Global South can make an important contribution to this task.

\section{References}

Amorim, Henrique. 2009. Trabalho Imaterial: Marx e o debate contemporâneo. São Paulo: Annablume.

Ampuja, Marko. 2013. Theorizing Globalization: A Critique of the Mediatization of Social Theory. Chicago, IL: Haymarket Books.

Ampuja, Marko. 2015. A Sociedade em Rede, o Cosmopolitismo e o "Sublime Digital": reflexões sobre como a História tem sido esquecida na teoria social contemporânea. Revista Parágrafo 1 (3).

Ampuja, Marko. 2016. The New Spirit of Capitalism, Innovation Fetishism and New Information and Communication Technologies. Javnost-The Public: Journal of the European Institute for Communication and Culture 23 (1): 19-36.

Antunes, Ricardo. 2001. Os Sentidos do Trabalho: ensaio sobre a afirmação e a negação do trabalho. São Paulo: Boitempo. 
Baccega, Maria Aparecida. 1998. Comunicação e Linguagem: discursos e ciência. São Paulo: Moderna.

Bourdieu, Pierre. 1983. O Campo Científico. São Paulo: Ática.

Canclini, Néstor García. 2005. Diferentes, Desiguais e Desconectados. Rio de Janeiro: Ed. UFRJ.

Casaqui, Vander; Riegel, Viviane. 2009. Google e o consumo do trabalho criativo. Comunicação, Mídia e Consumo 6 (17): 161-180.

Cortês, Norma. 2003. Esperança e Democracia: as ideias de Álvaro Vieira Pinto. Belo Horizonte: Ed. UFMG

Dantas, Marcos. 2012. Trabalho com Informação: valor, acumulação, apropriação nas redes do capital. Rio de Janeiro: Centro de Filosofia e Ciências Humanas da UFRJ.

Di Felice, Massimo. 2013. Net-ativismo e ecologia da ação em contextos reticulares. Contemporânea 11 (2): 267-283.

Figaro, Roseli. 2014a. A Comunicação Como Processo de Interação Verbal e Produção de Sentidos. In XXXVII Congresso Brasileiro de Ciências da Comunicação - Intercom 2014, Foz do Iguaçu/PR. Anais do Intercom 2014. Foz do Iguaçu: Intercom.

Figaro, Roseli. 2014b. O Campo da Comunicação e a Atividade Linguageira no Mundo do Trabalho Revista Chasqui 126.

Fuchs, Christian. 2016. Critical Theory of Communication: New Readings of Lukács, Adorno, Marcuse, Honneth and Habermas in the Age of the Internet. London: University of Westminster Press.

Fuchs, Christian. 2015. Culture and Economy in The Age of Social Media. London: Routledge.

Fuchs, Christian. 2014a. Digital Labor and Karl Marx. London: Routledge.

Fuchs, Christian. 2014b. Social Media: A Critical Introduction. London: Routledge.

Grohmann, Rafael. 2012. Os Discursos dos Jornalistas Freelancers Sobre o Trabalho: comunicação, mediações e recepção. Dissertation. São Paulo: Universidade de São Paulo.

Gusmão, Luís de. 2012. O Fetichismo do Conceito: limites do conhecimento teórico da investigação social. Rio de Janeiro: Topbooks.

Hall, Stuart. 2003. Codificação/Decodifixcação. In Da Diáspora: identidades e mediações culturais. Belo Horizonte: Ed. UFMG.

Hardt, Michael and Antonio Negri. 2005. Multidão. Rio de Janeiro: Record.

Hardt, Michael and Antonio Negri. 2004. Multitude: War and Democracy in the Age of Empire. New York: Penguin Press.

Hayles, Katherine. 1999. How We Became Posthuman. Chicago, IL: University of Chicago Press.

Huws, Ursula. 2014. Labor in the Global Digital Economy: the Cybertariat Comes of Age. New York: Monthly Review Press.

Huws, Ursula. 1999. Material World: the Myth of the 'Weightless Economy'. Socialist Register 35: 2955.

Illouz, Eva. 2011. O Amor nos Tempos de Capitalismo. Rio de Janeiro: Zahar.

Kerchove, Derrick de. 2009. A Pele da Cultura. São Paulo: Annablume.

Küklich, Julian. 2005. Precarious Playbour: Modders and the Digital Games Industry. Fibreculture Journal 3 (5).

Latour, Bruno. 2012. Reagregando o Social. Salvador/Bauru: EDUFBA/EDUSC.

Latour, Bruno. 2009. Jamais Fomos Modernos. Rio de Janeiro: Ed. 34.

Latour, Bruno. 2005. Reassembling the Social. New York: Oxford University Press.

Latour, Bruno. 1993. We Have Never Been Modern. Cambridge, MA: Harvard University Press.

Lemos, André. 2013. A Comunicação das Coisas: teoria ator-rede e cibercultura. São Paulo: Annablume.

Lévy, Pierre. 1999. Cibercultura. São Paulo: Edições 34.

Lévy, Pierre. 2014. A Esfera Semântica: tomo 1-computação, cognição e economia da informação. São Paulo: Annablume.

Lukács, György. 2012. Para uma Ontologia do Ser Social I. São Paulo: Boitempo.

Lukács, György. 1980. Ontology of Social Being—Labour. London: Merlin Press.

Lukács, György. 1978. Ontology of Social Being-Marx's Basic Ontological Principles. London: Merlin Press.

Marx, Karl. 1980. Teorias da mais-valia: história crítica do pensamento econômico. Rio de Janeiro: Civilização Brasileira.

Marx, Karl. 2011. Grundrisse. São Paulo: Boitempo.

Marx, Karl. 1973. Grundrisse. London: Penguin. 
Marx, Karl and Friedrich Engels. 2007. A Ideologia Alemã. São Paulo: Boitempo.

Marx, Karl and Friedrich Engels. 1969. Selected Works, Volume I. Moscow: Progress Publishers.

Marx, Karl and Friedrich Engels. 1939. German Ideology. New York: International Publishers, Inc.

Martini, Renato. 2009. Os intelectuais do ISEB, cultura e educação nos anos cinquenta e sessenta. Aurora 3 (5).

McGuigan, Jim. 2009. Cool Capitalism. London: Pluto.

McLuhan, Marshall. 1969. Os Meios de Comunicação como Extensões do Homem. São Paulo: Cultrix.

Mészáros, István. 2008. Filosofia, Ideologia e Ciência Social. São Paulo: Boitempo.

Morley, David. 2015. Televisão, Tecnologia e Cultura: uma abordagem contextualizada. Revista Parágrafo 1 (3).

Mosco, Vincent. 2009. The Political Economy of Communication. London: Sage.

Murdock, Graham. 2009. Comunicação contemporânea e questões de classe. Revista MATRIZes 2 (2): 31-56.

Pinto, Álvaro Vieira. 2005a. O Conceito de Tecnologia-Volume I. Rio de Janeiro: Contraponto.

Pinto, Álvaro Vieira. 2005b. O Conceito de Tecnologia—Volume II. Rio de Janeiro: Contraponto.

Pinto, Álvaro Vieira. 2008. A Sociologia dos Países Subdesenvolvidos. Rio de Janeiro: Contraponto.

Prado Jr., Bento. 1985. O problema da Filosofia no Brasil In: Alguns ensaios: filosofia, literatura, psicanálise, edited by Max Limonad, 173-194. São Paulo.

Ross, Andrew. 2009. Nice Work If You Can Get It: Life and Labor in Precarious Times. New York: New York University Press.

Rüdiger, Francisco. 2011a. As Teorias da Cibercultura. Porto Alegre: Sulina.

Rüdiger, Francisco. 2011b. As Teorias da Comunicação. Porto Alegre: Penso

Saad-Filho, Alfredo. 2011. O Valor de Marx. Campinas: Ed. Unicamp.

Santaella, Lúcia. 2007. Pós-humano-por que? Revista USP 74.

Santos, Boaventura de Sousa and Maria Paula Meneses. 2010. Epistemologias do Sul. São Paulo: Ed. Cortez.

Scolari, Carlos. 2008. Hipermediaciones. Barcelona: Gedisa.

Segata, Jean. 2014. A etnografia como promessa e o 'efeito Latour' no campo da cibercultura. Ilha 16 (2): 69-87.

Signates Luiz. 2013. O que é especificamente comunicacional nos estudos brasileiros de comunicação na atualidade? In 10 Perguntas para a Produção de Conhecimento em Comunicação, ed. José Luiz Braga, Jairo Ferreira, Antonio Fausto Neto, and Pedro Gilberto Gomes, 19-29. São Leopoldo/RS: Ed. Unisinos.

Sodré, Muniz. 2002. Antropológica do Espelho: uma teoria da comunicação linear e em rede. Petrópolis: Vozes.

Sodré, Muniz. 2012. Comunicação: um campo em apuros teóricos. Revista MATRIZes 5 (2): 11-27.

Sodré, Muniz. 2014. A Ciência do Comum: notas para o método comunicacional. Petrópolis: Vozes.

Weaver, Warren. 1978. A matemática da comunicação. In Comunicação e Indústria Cultural, ed. Gabriel Cohn. São Paulo: T.A. Queiroz.

Wiener, Norbert. 1967. Cibernética e Sociedade. São Paulo: Cultrix.

Williams, Raymond. 2005 [1980]. Culture and Materialism. London: Verso.

Williams, Raymond. 1977. Marxism and Literature. Oxford: Oxford University Press.

Williams, Raymond. 1960. Culture and Society, 1780-1950. New York: Anchor Books.

Wolton, Dominique. 2003. Internet, e depois? Uma teoria crítica das novas mídias. Porto Alegre: Sulina.

Žižek, Slavok. 2012. O ano em que sonhamos perigosamente. São Paulo: Boitempo

\section{About the Author}

Rafael Grohmann

$\mathrm{PhD}$ Candidate at the PostGraduate Programme in Communication Sciences of the University of São Paulo (USP) in Brazil. Professor in the Masters Programme in Journalism at the FIAM-FAAM University/Laureate International Universities, and at the Graduate Programme in Journalism at the Faculty of Social Communication Cásper Líbero. 